Rozalina POPOVA-KOSKAROVA

УДК 378.147:37(497.7)

Faculty of Pedagogy "St. Kliment Ohridski"

37.014.3

University "Sts. Cyril and Methodius" - Skopje

378.4(497.7)

Ljupčo KOSKAROV

University for audiovisual arts ESRA-Skopje

\title{
SOME CHALLENGES IN THE REALIZATION OF THE BOLOGNA PRINCIPLES FOR QUALITY TEACHER TRAINING
}

\begin{abstract}
This paper emphasizes the challenges in the realization of the principles of the Bologna Declaration at the Faculty of Pedagogy in Skopje. It is well known that the Bologna process began in 1999 as a result of the modern trend called globalization, which brought on great changes in all areas of life, including the education system. The Bologna process had the goal to standardize the university education in Europe in terms of several key issues or principles. Clearly, its most important characteristic is the European Credit Transfer System (ECTS), which places the student at the center of attention. This implies a set of competencies including general, i.e. generic and professional.

The subject of our theoretical analysis refers to the challenges in the realization of the Bologna principles, which in our area of scientific work stress the need of quality teachers. For this purpose, the realization of the following principles was crucial: student focused activity, lifelong learning, mobility, institution partnership, common qualification framework, etc. Did we succeed? Unfortunately, we faced many obstacles, which were confirmed by our analysis of the study programs, starting from the very implementation of ECTS in 2005 until today.
\end{abstract}

Key words: Bologna, principles, challenges, quality teacher

\section{Introduction}

The process of globalization and integration, imposed at the end of the XIX century, starting from the economy expanded to other areas as well, such as culture, politics, health, education, law, etc. Regarding education, a special place was given to the uniting idea of the common European education area, which in the context of higher education, resulted in the signing of the Bologna Declaration in Prague in 2001. This set the bases of the so called European Higher Education Area, with the goal to adapt the qualifications of the European citizens on a common basis, for greater mobility, flexibility and easier employment, personal development and success in life and work (Popova Koskarova, 2011).

The Republic of Macedonia, as one of the signatory countries of the Bologna Declaration in 2003 in Berlin, was obligated to enforce the principles of Bologna. The main precondition was to provide quality that will guarantee a 
minimal level of cohesion, i.e. compatibility with the higher education, resulting in ECTS. The following were the common elements: providing quality, academic accreditation, European qualifications framework, mobility and transfer of students and teaching staff, and most importantly student focused activity. In our paper, in the context of the above mentioned, all numbered common elements refer to training teaching staff. Hence, we pose the following question: How successful have we been at doing this?

\section{The Bologna process and training teachers}

The quality training of the teaching staff has been a part of Europe's agenda for quite some time. Namely, the declaration for "Strengthening the role of the teacher in a changing world" (Arnaudova, 2005:26) was signed in 1996 in Geneva. It emphasizes the need of training quality teachers who bring the changes in the society and the rapidly changing world.

In 2005, the European Commission (whose purpose is to promote integration and sense of unity within the Union) set the quality principles (standards) of the teaching profession, which can be summarized through 4 aspects: first, the teaching profession is regulated, i.e. it is academic. This means that anyone who wishes to be employed as a teacher should have a degree, at least from the first cycle of studies. The qualifications framework planned the possibility of integrating first and second cycle of studies, i.e. gaining master's title (master title for teachers, as it is the case in Norway).

The second characteristic was to provide quality education for the future teachers, with the goal to train quality teachers, as the leading principle in education. Closely related to this principle is the principle of lifelong learning in the area of the teaching profession, which, apart from pre-service training also implies intensifying the in-service training.

The third principle, which refers to the quality of the teaching profession is the need of mobility, which does not only imply mobility within Europe, but also the possibility to gain work qualifications for another subject, or work in another school, which can be characterized as internal mobility.

The fourth principle refers to the need to intensify the practical training through partnership with the institutions, as well as by establishing partnership with schools and preschool institutions.

The first step in enforcing these principles imposed regional standardizing of the curriculum, i.e. the Tuning Project. For this purpose, competencies were determined, and so called descriptors, i.e. expected learning results, which the future teachers will have. The competencies are in fact knowledge, skills, attitudes, i.e. values which should be acquired through the process of education at the faculties. This was supposed to be accompanied by revision of the syllabi, eliminating the overlapping of the material in the syllabi and a clear definition of the competencies of the given profile.

This led to defining general, generic and specific competencies. 
According to a research carried out in 2002, the following competencies were isolated as the most important general competencies: communication competence, ethical competence, ability for analytic-synthetic approach, quality awareness and use of the attained knowledge in practice, learning capacity, i.e. continuous professional development, etc.

The list of professional competencies is quite long, and we believe that there is no need to present it here.

Defining the competencies required organization and precision.

\section{Challenges (difficulties) in the realization of the principles}

Ten years after implementing ECTS, we can see where we are with the realization of Bologna. Namely, starting from 2004/2005, we can undoubtedly see shortcomings and contradictions which brought the realization of the Bologna process into question, and all these shortcomings also reflected the quality of the education of the staff.

The first great shortcoming, according to the author of the text is the mechanical transformation of the two-semester subjects into one-semester (now called courses), naturally with an increased number of lessons. The Bologna Declaration recommended modules, i.e. courses, which we saw as teaching subjects, although modules are not in fact teaching subjects. According to our understanding, the modules were seen simply as teaching subjects, rather than as units with a formal structure and determined expected learning results. In fact, the modules, i.e. courses were supposed to allow achieving the expected results from the subject programs. In the beginning, it was also challenging to determine the number of credits for each course, since this implied taking into consideration several aspects: learning time, time for writing an essay or paper, instructional time, etc. In fact, this was the first challenge we faced, since it was believed that the subjects (courses) which bring a higher number of credits are more important than the ones with a lower number. On the other hand, the transformation of the courses into one-semester courses resulted in difficulties in the realization of some subjects, or there was material reduction, which later reflected in the quality of the instructional process. Instead of student focused instruction, the teachers focused on material realization, i.e. realization of the goals and tasks of the program. "The attention of instruction is faced towards the realization of the lesson, rather than how the lesson influences the students, the effects it causes in terms of the knowledge, i.e. the type of developed skills and attitudes". (Arnaudova, 2006). As stressed by professor Violeta Arnaudova, "the least amount of attention is devoted to how students apply gained knowledge, skills and attitudes in real life situations" (same, p. 26). Instead of profound knowledge, students acquired superficial knowledge, which reflected in the staff quality. The students' interest in reading additional literature decreased, and the basic source of knowledge was the instructional material, i.e. the textbook. Some universities even posted the lectures on their websites in the form of PowerPoint presentations, and these were the only source for exam preparation. 
2.1. The way of evaluating knowledge (assessment) is another aspect which badly influenced the quality of the future teacher. Namely, the Bologna Declaration recommended the abandonment of the ex cathedra, i.e. the traditional way of instruction where the teacher is merely a lecturer, and the students are the passive audience. As opposed to this Bologna recommended more tests, workshops, homework, projects, seminar papers, essays, etc., presentations during classes, i.e. activities for continuous learning. (Avramovic, 2003). Apart from the fact that the Bologna Declaration did not recommend the exclusive use of a written evaluation of knowledge, this way of knowledge evaluation prevailed. According to us, this is another inadequately used characteristic of Bologna, which led to decreased communication between the teachers and the students. This reflected especially negatively in the larger faculties which enrolled up to 800 students, such as the faculties of Law and Economy which opted for optical reading of the tests. Namely, circling one of the alternative answers to 10 or more questions substituted the live contact, communication between the teacher and the students, i.e. the oral assessment of knowledge, the way in which the students think, see things, their attitudes, etc. Thus, instead of developing critical thinking, the students became passive participants in the educational process which should have placed them at the center of attention. This raises the question if it is possible to educate quality teachers if they are not placed in the position to think critically and to have communication skills. Our practice shows that the students are characterized with a poor register and that their communication skills are at a quite low level, characteristics which the future teachers in no way should possess. The presentations which were a part of the activities of the students during the drills, were not enough to compensate for the shortcomings of the dominant way of evaluating knowledge.

The greatest shortcoming in this aspect was the insufficient monitoring and assessment of the ability of the students to use the acquired knowledge, and their ability for evaluating, i.e., assessing and developing attitudes, communication and other skills, in other words everything in the domain of the functional task of education. Although the educational component was dominant, it was not realized with the purpose to answer to the requirements of the times in which knowledge becomes obsolete very fast, and the rapidly changing world, thus achieving the expected results was realized with difficulty. Hence, the quality of education did not increase, moreover, it rapidly decreased, and soon enough we were all aware that we should change something in the essence of the entire process.

Mobility (transfer) of students via the Erasmus Program at some faculties, such as the Faculty of Pedagogy, was hardly realized, one of the reasons being poor understanding of the English language. On the other hand, we should not neglect to mention that the differences in the education systems in Europe are the most complex. The influence of tradition and the national identity are important characteristics which are hard to avoid. Hence, it was difficult for students to begin their teacher training in Skopje and finish it in England or Sweden. 
Although, according to the Bologna principles, practical training is one of the most important tasks in the education of the staff, especially regarding the profile of the teachers, we have to admit that within the actual realization there are a lot of shortcomings. Namely, some teacher faculties were faced with a great number of students (such as the Faculty of Pedagogy), and were unable to allocate their students in only two partner schools. Hence, the practical training, which should be the pillar in the training of the teaching staff, is yet to be realized true to word.

2.2. The change of the syllabi is one of the most important characteristics that resulted from the Bologna Declaration. This implies modernization with new material and courses on one hand, and an opportunity to standardize the curriculum in the frames of the common European area on the other hand. However, unfortunately this component was not elaborated sufficiently according to the principles of the Bologna Declaration. Our analysis in this context, showed that the reform changes of the curriculum in 2011, left the students at the Faculty of Pedagogy in Skopje with 42 compulsory subjects and 16 elective subjects. Along with the pedagogical practice, realized during 60 hours across 4 years, pedagogical internship with 45 hours and a diploma work, a total of 62 compulsory subjects, which is a lot i.e. too much. The form has come above the substance. The shortcomings of this study program soon came to light, and three years later there was a new revision of the study plan, i.e. the number of teaching subjects was decreased, and now with the current study program (curriculum) the number of compulsory subjects is 27 and the number of elective subjects is 7 , i.e. together with the pedagogical practice and internship in year four, the total number of subjects is 38 .

The way of study, according to Bologna provided opportunities for shorter duration of the studies. In this context, there is a research carried out by professor Vukasovic in 2006, which had the goal to determine the achievements of the students before and after implementing the Bologna Declaration. The research showed that before the implementation of the Bologna Declaration, the studies lasted longer on average than after its implementation, and around 55\% of the students graduated before the Bologna Declaration. (Vukasovic, 2006). However, this research does not give us the right to conclude that the positive results are radical, although they are obvious (Maksimovic, 2012).

\section{Conclusion}

We may conclude that the idea of the Bologna process, based on the principle of common European education area, is quite advanced. However, its realization in the universities is inadequate in terms of many segments and it is accompanied by many contradictions which we pointed out, especially in the area of teacher training. Naturally, if the universities manage to overcome these challenges, there could be opportunities for more successful studies, based on continuous learning, engagement and student focused activities, and of course, a new role of the university teachers. 


\section{Literature}

1. Аврамовић, 3. (2003). Држава и образовање. Београд: Институт за педагошка истраживања.

2. Арнаудова, В. (2007). Идентификација на компетенции неопходни за успех во наставниот процес, зборник Современи тенденции во формирањето на наставниот кадар за предучилишното вопситание и одделенската настава. Скопје: Универзитет Св.Кирил и Методиј, Педагошки фаултет Св. Климент Охридски.

3. Максимовић, J. (2012). Противуречја болоњског процеса у високом образовање Србије, зборник Образовање и савремени универзитет. Ниш: Универзитет у Нишу, 81-93.

4. Попова-Коскарова, Р. (2006). Европскиот кредит трансфер систем и неговите импликации во високото образование во Р. М со посебен акцент на едукативниот процес на педагошките факултети, Педагошка практика, бр. 1-2, 83-87.

5. Popova-Koskarova, R. (2011). Key European Competences and Human Development of Personality, зборник Васпитање за хумане односе, проблеми и перспективе. Ниш: Универзите у Нишу.

Розалина Попова Коскарова

Љупчо Коскаров

\section{ОДРЕЪЕНИ ИЗАЗОВИ У ПРИМЕНИ БОЛОЮСКИХ НАЧЕЛА У СВРХУ КВАЛИТЕТНОГ УСАВРШАВАҢА ПРЕДАВАЧА}

Резиме: Овај рад говори о изазовима током примене начела Болоюске деклараџије на Педагошком факултету у Скопљу. Познато је да је Болоњски прочес почео 1999. године, као резултат модерног тренда званог глобализација, који је довео до великих промена у свим подручјима живота, укључујући и образовни систем. Болоюски прочес је имао за ичиљ стандардизаџију високог образовања у Европи у погледу неколико кључних питања или принципа. Наиме, његова најважнија карактеристика је европски систем преноса и акумулаиије бодова (European Credit Transfer System - ECTS), који ставља студента у центар пажње. Овим се подразумева скуп вештина и знања укључујући опите, т.j. генеричке као и професионалне вештине.

Предмет наме теоријске анализе односи се на изазове у примени Болоњских начела, за чију је примену на нашем подручју научног рада потребно присуство квалитетних предавача.У ту сврху, остваривање следећих принципа било је кључно: активности усмерене на ученике, целоживотно учење, мобилност, партнерства међу институцијама, јединствени скуп потребних квалификација, ито. Да ли смо успели? Нажалост, суочили смо се са многим препрекама, што смо и потврдили помоћу наше анализе студијских програма, почевии од саме имплементације европског система преноса и акумулаџије бодова (ECTS), од 2005. године до данас.

Кључне речи: Болоња, начела, изазови, квалитетни предавачи.

Примљено: 02. 06. 2015. године.

Одобрено за штампу: 08. 02. 2017. године. 